\title{
Pelatihan Keterampilan Berbicara Untuk Meningkatkan Kemampuan Berbicara Didepan Umum Pada Himpunan Mahasiswa Progam Studi Pendidikan Bahasa Indonesia Universitas Nahdlatul Ulama Blitar Tahun 2019
}

\author{
${ }^{1}$ Agus Hermawan, ${ }^{2}$ Bagus Waluyo \\ ${ }^{1}$ Progam Studi Pendidikan Bahasa Indonesia \\ ${ }^{2}$ Program Studi Pendidikan Bahasa Inggris \\ ${ }^{1,2}$ Universitas Nahdlatul Ulama Blitar \\ 1 agushermawan8992@gmail.com \\ ${ }^{2}$ waluyobagus81@gmail.com
}

\begin{tabular}{l}
\hline Tersedia Online di \\
\hline http://www.jurnal.unublitar.ac.id/ \\
index.php/briliant
\end{tabular}

Sejarah Artikel

Diterima pada 11 Ferbruari 2019

Disetuji pada 17 Februari 2019

Dipublikasikan pada 20 Februari

2019 Hal. 113-117

Kata Kunci:

Berbahasa, terampil, berbicara.

DOI:

http://dx.doi.org/10.28926/briliant .$v 3 \mathrm{i} 3.276$
Abstrak: Keterampilan berbahasa produktif salah satunya adalah keterampilan berbicara, keterampilan ini sangat berpengaruh dan menunjang keterampilan berbahasa yang lainnya. Untuk itu keterampilan berbicara wajib diasah dengan baik, tentunya untuk menyampaikan ide dan gagasan dengan sebaik-baiknya. Umumnya seorang penutur/pembiacara adalah orang yang harus handal menguasai topik yang dimunculkan. Pembicara yang baik tentu dapat memotivsi pendengar/penyimak agar tidak jenuh. Penutur yang baik mampu memudahkan pendengar menangkap isi pembicaraan.

\section{PENDAHULUAN}

Berbicara bagian dari salah satu dari empat aspek berbahasa. Berbicara adalah keterampilan berbahasa yang berkembang pada diri seseorang. Keterampilan berbicara dimulai dari keterampilan menyimak dahulu, kemudian disaat bersamaan keterampilan berbicara mulai belajar berujar apa yang sudah didengarkannya. Manusia sebagai mahluk sosial yang tidak bisa hidup sendiri sangat memerlukan keterampilan berbahasa untuk komunikasi dengan sesamanya. Bukti betapa pentingnya berbicara dalam kehidupan manusia dalam masyarakat dapat berupa aneka wacana, mulai dari lingkungan terkecil: keluarga, kumpulan sosial, agama dan budaya.

Budaya manusia dewasa ini mengajak untuk terampil berkomunikasi , menyatakan pendapat, gagasan, ide, hingga perasaan. Terbukti dalam masyarakat terdapat aspek-aspek yang digunakan dalam menilai seseorang berdasarkan tuturannya. Pendidikan formal maupun non formal berperan penting dalam membentuk kepribadian seseorang dalam bertutur kata. Sopan santun dalam tata krama berbicara dapat dilatihkan dan dibina mulai dari lingkungan keluarga. Norma-norma adat dan budaya masyarakat diterapkan dalam bentuk lisan. 
Keterampilan berbicara mempunyai beberapa ciri, menyebutkan bahwa keterampilan berbicara memiliki empat bagian pokok materi: 1) dimensi rasional, tujuan dan cakupan, fungsi dan relevansinya dalam berbicara, 2) hakikat berbiacara yang terdapat pengertian, tujuan, dan fungsi berbicara serta konsep berbicara, 3) faktor yang mempengaruhi efektivitas berbicara, 4) pengembangan keterampilan berbiacara yang meliputi pengajaran berbicara, dan paraktik berbicara dengan berbagi tema.

\section{METODE PELAKSANAAN}

Metode untuk pemecahan masalah yang digunakan untuk ini mencakup: (1) pelatihan yang meliputi paradigma PPM keterampilan metode atau teknik yang digunakan dalam keterampilan berbicara, (2) pelatihan yang meliputi praktek berbicara,(3) partisipatori, dan (4) penugasan. Sasaran kegiatan dalam pengabdian ini pada masyarakat Sasaran kegiatan dalam pengabdian pada masyarakat ini adalah pelatihan keterampilan berbicara untuk meningkatkan kemampuan berbicara didepan umum pada himpunan mahasiswa progam studi pendidikan bahasa indonesiaYang mempunyai kemauan/minat besar dalam mengembangkan profesionalisme pekerjaan serta dalam masa pengabdian ke masyarakat.

Adapun tahapan melakukan kegiatan pengabdian pada masyarakat ini mencakup tiga kegiatan; (1) melakukan bimbingan terkait tata krama berbicara. Dalam kegiatan pertama ini faktor-faktor pendukung pelaksanaan bimbingan telah disiapkan, (2) penugasan dan pendampingan, (3) melakukan seminar hasil PPM.

Mitra berkolaborasi dengan tim pengusul dalam mendukung penyelenggaraan bimbingan teknis ini. Mitra bertugas dalam melakukan koordinasi, promosi, dan pendataan terhadap peserta yang akan mengikuti bimbingan. Mitra juga menjamin kesediaan peserta untuk mengikuti bimbingan.

Jenis evaluasi yang digunakan dalam progam pengabdian kepada masyarakat ini adalah menggunakan bentuk ; (1) Pre-test, yaitu persepsi pengurus himaprodi tentang keterampilan berbicara, (2) Post-test yaitu mengevaluasi pengurus himaprodi Setelah bimbingan teknis berakhir dilakukan fasilitasi kepada pengurus himaprodi untuk menerapkan kegiatan pendampingan keterampilan berbicara yang telah dilaksanakan dan mempublikasikan artikel hasil PPMnya di Jurnal Ilmiah.

\section{HASIL DAN PEMBAHASAN}

Kegiatan PPM yang dilaksanakan dengan cara tatap muka dan praktek keterampilan berbicara berjalan dengan baik dan lancar. Pertemuan pertama dengan metode ceramah dan demonstrasi, dilanjutkan dengan praktek untuk menerapkan keterampilan berbicara dengan beberapa syarat-syarat tata krama berbicara. Kegiatan ini dilaksanakan sehari yaitu pada Sabtu, 20 Desember 2018 pukul 13.30-16.30 WIB. Peserta kegiatan berjumlah 15 orang pengurus himaprodi Pendidikan Bahasa Indonesia Fakultas Ilmu Pendidikan dan Sosial Universitas Nahdlatul Ulama Blitar.

Pelaksanaan kegiatan PPM ini dilakukan oleh 2 (dua) orang tim pengabdi dengan pokok bahasan yang disampaikan mengenai:

1) Pengantar Materi keterampilan berbicara;

2) Teori keterampilan berbicara; 
3) Langkah-langkah Optimalisasi Kemampuan berbicara;

4) Latihan keterampilan berbicara dalam berbagai kepentingan;

5) Evaluasi hasil kemampuan berbicara.

Keterbatasan waktu pertemuan mengakibatkan tidak semua materi dapat disampaikan dengan detail. Kegiatan yang diawali dengan ceramah dan demonstrasi ini kemudian dilanjutkan latihan. Dari kegiatan latihan tampak bahwa mitra memang belum menguasai tata cara berbicara yang baik, khususnya terkait penggunaan bahasa baku formal dalam bahasa Indonesia. Acara kemudian dilanjutkan sesi tanya jawab.

Berbagai pertanyaan diajukan secara antusias oleh para peserta dalam sesi tanya jawab. Secara garis besar inti dari pertanyaan para peserta adalah:

1) Penggunaan bahasa dalam keterampilan berbicara yang baik

2) Penggantian kata ganti orang yang sesuai dalam keterampilan berbicara

3) Pengaturan kemampuan berbicara didepan umum yang sesuai

4) Analisis kesalahan berbahasa dalam kemampuan berbicara yang telah dilakukan

Program pengabdian pada masyarakat berupa pelatihan keterampilan berbicara untuk meningkatkan kemampuan berbicara didepan umum pada pengurus himpunan mahasiswa progam studi pendidikan bahasa Indonesia Universitas nahdlatul ulama blitar tahun 2019 yang sudah dilaksanakan ini diharapkan dapat menambah pengetahuan, keterampilan dan lebih percaya diri dalam keterampilan berbicara. Mitra akan lebih semangat dan termotivasi untuk mengembangkan diri. Hasil pelatihan ini akan bermanfaat bagi organisasi, khususnya dalam hal keterampilan berbicara dengan memperhatikan kesalahan penggunaan bahasa. disamping itu dengan adanya pelatihan keterampilan berbicara ini akan menambah keterampilan berbicara pada pengurus dalam menyiapkan diri untuk kepentingan tertentu sehingga akan mendukung kemampuan pengurus dalam menyampaikan sesuatu didepan umum.

Hasil kegiatan PPM secara garis besar mencakup beberapa komponen sebagai berikut:

1. Keberhasilan target dan jumlah peserta pelatihan ;

2. Ketercapaian tujuan pelatihan;

3. Ketercapaian target materi;

4.Kemampuan peserta dalam penguasaan materi.

Target peserta pelatihan seperti direncanakan sebelumnya adalah paling sedikit tidak 15 pengurus himpunan mahasiswa progam studi pendidikan bahasa Indonesia sesuai dengan jumlah pengurus yang ada. Dalam pelaksanaanya, kegiatan ini diikuti oleh 15 orang peserta. Dengan demikian dapat dikatakan bahwa target tercapai 90\%. Angka tersebut menunjukkan bahwa kegiatan PPM dilihat dari jumlah peserta yang mengikuti dapat dikatakan berhasil/sukses.

Ketercapaian tujuan pendampingan pelatihan berbicara berjalan dengan baik, namun keterbatasan waktu yang disediakan mengakibatkan tidak semua materi tentang tata krama berbicara didepan umum dapat disampaikan secara rinci. Namun dilihat dari hasil latihan para peserta yaitu kualitas penggunaan bahasa baku dan tidak baku telah dihasilkan, maka dapat disimpulkan bahwa tujuan kegiatan ini tercapai. Ketercapaian target materi pada kegiatan PPM ini cukup baik, karena materi pendampingan dan pelatihan dapat disampaikan secara keseluruhan. Materi pendampingan yang telah disampaikan meliputi; 
1) Pengantar keterampilan berbicara;

2) Teori keterampilan berbicara;

3) Langkah-langkah Optimalisasi Kemampuan berbicara;

4) Latihan keterampilan berbicara dalam berbagai kepentingan;

5) Evaluasi hasil kemampuan berbicara.

Kemampuan peserta pelatihan dalam penguasaan materi masih kurang karena waktu yang singkat dan kemampuan yang berbeda. Hal ini disebabkan jumlah materi yang banyak disampaikan dalam waktu sehari sehingga tidak cukup waktu. Secara keseluruhan kegiatan pelatihan keterampilan berbicara untuk mengedukasi tentang tata krama berbicara didepan umum dan penggunaan bahasa baku dan tidak baku dalam keterampilan berbicara menurut konteksnya. Keberhasilan ini selain diukur dari keempat komponen diatas, juga dapat dilihat dari kepuasan peserta setelah mengikuti pelatihan. Manfaat yang diperoleh mahasiswa adalah bisa membantu pembelajaran keterampilan berbicara dengan kualitas yang lebih baik dan diharapkan kualitas tersebut sudah mengikuti syarat dalam keterampilan berbicara.

\section{KESIMPULAN}

Progam pendampingan dapat diselenggarakan dengan baik dan berjalan lancar sesuai dengan rencana kegiatan yang telah disusun meskipun belum semua peserta pelatihan menguasai materi dengan baik dengan materi yang disampaikan. Kegiatan ini mendapat sambutan baik dengan keaktifan peserta mengikuti pelatihan dengan tidak meninggalkan tempat sebelum pelatihan berakhir.

\section{SARAN}

Pihak kampus khususnya dilingkungan universitas nahdlatul ulama blitar diharapkanlebih proaktif terhadap pertumbuhan dan perkembangan kegiatan himaprodi sebagai organisasi tingkat bawah yang perlu pendampingan dan pengawasan. Perlu dilakukan kerjasama antara prodi dan fakultas untuk menciptakan suasana akdemik dan memberikan bimbingan teknis lanjut tentang kemampuan berbahasa.

\section{DAFTAR RUJUKAN}

Arsjad dan Mukti U.S. (1993). Kemampuan berbicara. Jakarta: PT Gramedia Tarigan, Henry. (1983). Berbicara sebagai suatu keterampilan berbahasa. Jakarta: PT Gramedia

Tarigan, Henry. (2008). Berbicara. Jakarta: PT Gramedia

Tarigan, Djago. (1990). Berbicara adalah keterampilan menyampaikan pesan melalui bahasa lisan. Jakarta: PT Gramedia 